\title{
Spatial and temporal patterns of settlement among sparid fishes of the genus Diplodus in the northwestern Mediterranean
}

\author{
Laurent Vigliola ${ }^{1}$, Mireille L. Harmelin-Vivien ${ }^{1, *}$, Franco Biagi $^{2,3}{ }^{3}$, René Galzin ${ }^{4}$, \\ Antoni Garcia-Rubies ${ }^{5}$, Jean-Georges Harmelin ${ }^{1}$, Jean-Yves Jouvenel ${ }^{4}$, \\ Laurence Le Direach-Boursier $^{1,6}$, Enrique Macpherson ${ }^{5}$, Leonardo Tunesi ${ }^{7}$ \\ ${ }^{1}$ Centre d'Océanologie de Marseille, CNRS UMR 6540, Université de la Méditerranée, Station Marine d'Endoume, \\ F-13007 Marseille, France \\ ${ }^{2}$ Università di Pisa, Dipartimento di Scienze dell'Uomo e dell'Ambiente-DSUA, Via A. Volta 6, I-56100 Pisa, Italy \\ ${ }^{3}$ Centro Interuniversitario di Biologia Marina ed Ecologia Applicata-CIBM, I-57127 Livorno, Italy \\ ${ }^{4}$ Ecole Pratique des Hautes Etudes, CNRS URA 1453, Université de Perpignan, F-66860 Perpignan Cedex, France \\ ${ }^{5}$ CSIC, Centro de Estudios Avanzados de Blanes, Camino de Santa Barbara, E-17300 Blanes, Girona, Spain \\ ${ }^{6}$ GIS Posidonie, Parc Scientifique el Technologique de Luminy, Case 901, F-13288 Marseille Cedex 09, France \\ ${ }^{7}$ ICRAM, Via L. Respighi 5, I-00197 Roma, Italy
}

\begin{abstract}
Juvenile settlement of 3 sparid fish species, Diplodus puntazzo, Diplodus sargus and Diplodus vulgaris, was studied over 3 yr at 20 stations located at 5 sites in the NW Mediterranean Sea: 1 site in Spain (Girona), 2 in France (Banyuls and Marseille) and 2 in Italy (Portofino and Elba). When all sites and years were combined, $71 \%$ of the settlers recorded belonged to $D$. vulgaris, $25 \%$ to $D$. sargus and $4 \%$ to $D$. puntazzo. Settlement was seasonal, with $D$. sargus settling in May-June, $D$. puntazzo in October-November, and D. vulgaris in 2 pulses, the first in November-December and the second in January-February. Settlement intensity varied spatially, temporally, and among species. At a small spatial scale (within site), settlement intensity varied between stations and particularly between years. At a large spatial scale (among sites), settlement intensity varied among sites, with Marseille and Girona generally experiencing higher settlement than other sites. No difference in settlement intensity was observed between protected and unprotected areas. The settlement of D. sargus was higher in 1994 than in 1993 and 1995 at all sites, suggesting the influence of meso-scale hydroclimatic conditions on the settlement success of this species. The settlement of D. vulgaris was higher in 1993 in the western part of the NW Mediterranean, and in 1994 in the eastern part. No consistent spatial trend over time was seen for D puntazzo. Thus, settlement intensity of Diplodus species to nearshore habitats in the NW Mediterranean exhibited high year-to-year variations at both local and regional scales.
\end{abstract}

KEY WORDS: Settlement Sparid fish - NW Mediterranean - Spatial variability - Temporal fluctuations

\section{INTRODUCTION}

Many fish species inhabiting the nearshore habitats of the NW Mediterranean Sea are of great importance to artisanal fisheries, less so for the biomass of their catches than for their high value relative to Atlantic species (Bas et al. 1984). Despite the growing interest in these species, many aspects of their biology remain

\footnotetext{
- Addressee for correspondence.

E-mail: harmelin@com.univ-mrs.fr
}

unknown, particularly their spatial and temporal patterns of settlement into benthic habitats. Fluctuations in settlement and juvenile recruitment may influence the population dynamics of fish species and are potential determinants of the sizes of local populations and exploitable fish stocks (Beverton \& Holt 1957, Beverton 1984, Connell 1985, Cushing 1988). Recruitment of juvenile fishes may be highly variable at different spatial scales, from metres to hundreds of kilometers. Large interannual variations in the intensity of recruitment may also occur (Shulman 1985, Fowler et al. 
1992, Doherty \& Fowler 1994). In temperate zones many studies of juvenile recruitment of benthic fishes have been done for gadids (Lough et al. 1989, Folkvord et al. 1994), flatfishes (Rıley et al. 1981. Berghahn 1986, Bolle et al 1994, Miller 1994, Pauly 1994), scorpaenids (Carlson \& Straty 1981, Carr 1991), labrids (Tupper \& Boutulier 1995, Levin 1996) or sea bass (Jennings \& Pawson 1992) Data on the recruitment of benthic coastal fishes, particularly sparids, in the Mediterranean Sea are scarce, and generally related to the arrival of 0-group fishes in bays or coastal lagoons (Cambrony 1984, Quignard et al. 1984, Jug-Dujakovic 1988). No quantitative information is available for sparid fishes on rocky shores, except for a few studies on the microhabitat requirements at settlement of severa] species (Garcla-Rubles \& Macpherson 1995 Harmelın-Vivien et al. 1995, Blagı et al. 1997). Sparıd fishes of the genus Diplodus live in coastal habitats, from shallow waters down to $>50 \mathrm{~m}$ deep, with reproduction taking place in deep waters (Divanach 1985) After 1 mo of larval life, they settle in very shallow benthic habitats, where they remain for several months. After reaching 4.5 to $5.5 \mathrm{~cm}$ in length, the juvenules of the 3 species studied here disperse outside the nursery area to join the adult population (Macpherson 1998)

In this study, the spatial and temporal patterns of settlement were analysed for 3 species of Sparidae from the genus Diplodus at local and regional spatial scales over 3 consecutive years Results were combined from several contemporaneous studies done from May 1993 to June 1996 at 5 sites located in Spain. France and Italy. These data allowed a multiscale assessment of Diplodus settlement in the NW Mediterranean Sed over a linear distance of $>600 \mathrm{~km}$. The influence of protection level on fish settlement was also tested by sampling inside and outside marine protected areas

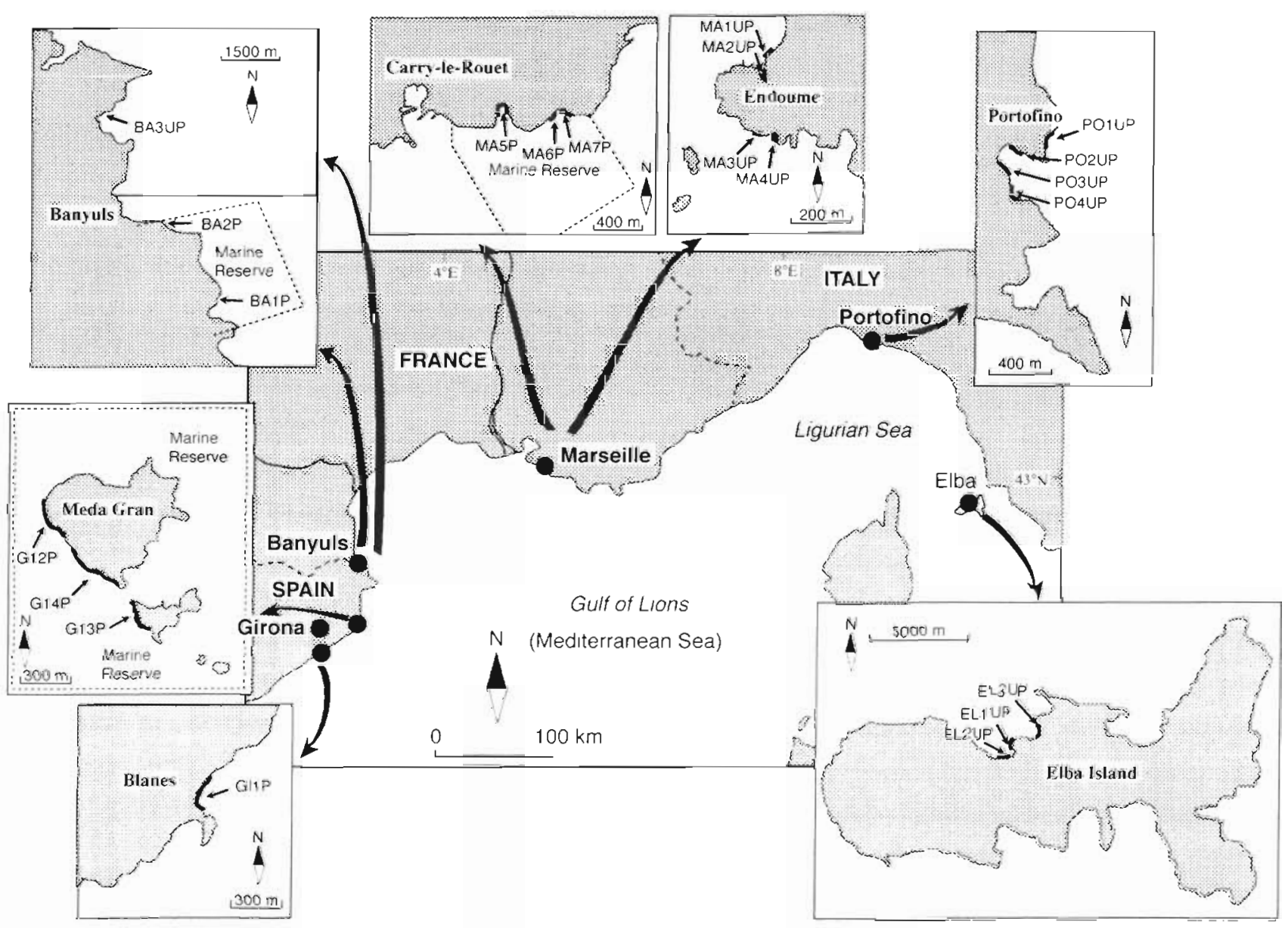

Fig. 1. Locations of the 5 sites studied in the NW Mediterranean Sea, showing stations sampled at each site Marne protected areas are delineated with dashed lines Location of stations in protected (P) or unprotected zones (UP) 15 indicated by station abbreviation. Three stations were studied in Girona (GI1UP. $300 \mathrm{~m}$ in length, GI2P: $150 \mathrm{~m}$, GI3P $150 \mathrm{~m}$ ), $3 \mathrm{in}$ Banyuls (BA1P 238 m, BA2P: 189 m, BA3UP: 208 m), 7 In Marseille (MA1UP: 27 m, MA2UP: 24 m, MA3UP 30 m, MA4UP 32 m, MA5P 335 m, MA6P: $129 \mathrm{~m}$. MA7P $176 \mathrm{~m}$ ) 4 in Portofino (PO1UP: $63 \mathrm{~m}$, PO2UP: $73 \mathrm{~m}$, PO3UP: $74 \mathrm{~m}$, PO4UP 104 m), and 3 at Elba Island (EL1UP $165 \mathrm{~m}$. EL2UP $148 \mathrm{~m}$, EL3UP $106 \mathrm{~m}$ ) 
when possible. Following the definitions of Gibson (1994) and Levin (1994), 'settlement' corresponds to the arrival of new individuals from the pelagic habitat into benthic habitats, and 'recruitment' is the number of juveniles surviving an arbitrary period of time (generally a few months) after settlement.

The specific objectives in this study were 3-fold: (1) to quantify the spatial and temporal variability in the timing of settlement, (2) to quantify the spatial and temporal variability in the magnitude of settlement, and (3) to test whether settlement differs between protected and unprotected areas.

\section{MATERIAL AND METHODS}

Study sites. Settlement of 3 sparid fish species, Diplodus puntazzo, Diplodus sargus and Diplodus vulgaris was studied at 5 sites located along the NW coast of the Mediterranean Sea: 1 site in Spain (Girona), 2 in France (Banyuls and Marseille), and 2 in Italy (Portofino and Elba) (Fig. 1). At each site, 3 to 7 stations, located in protected and non protected areas when possible, were sampled. All 20 stations were located in known nursery areas: shallow water coves protected from prevailing winds and presenting a gentle slope with coarse sand, gravel, pebbles or boulders (Garcia-Rubies \& Macpherson 1995, Harmelin-Vivien et al. 1995). The sizes of the stations differed depending on the morphological characteristics of the coast and ranged between 24 and $335 \mathrm{~m}$ in length (Fig. 1).

Methods. Visual censuses were performed weekly at each station from May 1993 to June 1996. Intercalibration of teams was done prior to the start of sampling to minimize biases due to different observers. Censuses were conducted along shore, from the surface to $7 \mathrm{~m}$ using snorkels and SCUBA; this depth range encompassed the entire vertical distribution of settlers of the 3 species. Juvenile sparids were counted and their length estimated (in $5 \mathrm{~mm}$ size classes) during each census using a plastic board bearing silhouettes of individuals of different sizes. Four replicate censuses were made at all stations except for the protected stations at Marseille, where 1 census per week was conducted. Data were not collected in 1993 for Diplodus sargus in Banyuls, Portofino and Elba. Data were not collected for D. vulgaris in Banyuls in 1995. The duration of each dive ranged from $30 \mathrm{~min}$ (stations $<50 \mathrm{~m}$ in length) to $2 \mathrm{~h}$ (stations $>300 \mathrm{~m}$ in length). As visual counts were performed with a weekly periodicity, we assumed that the date of first count was not very different from the date of first settling. To study the spatial and temporal patterns of benthic settlement, we decided to take into account the maximum number of individuals $(N)$ recorded at each station each year

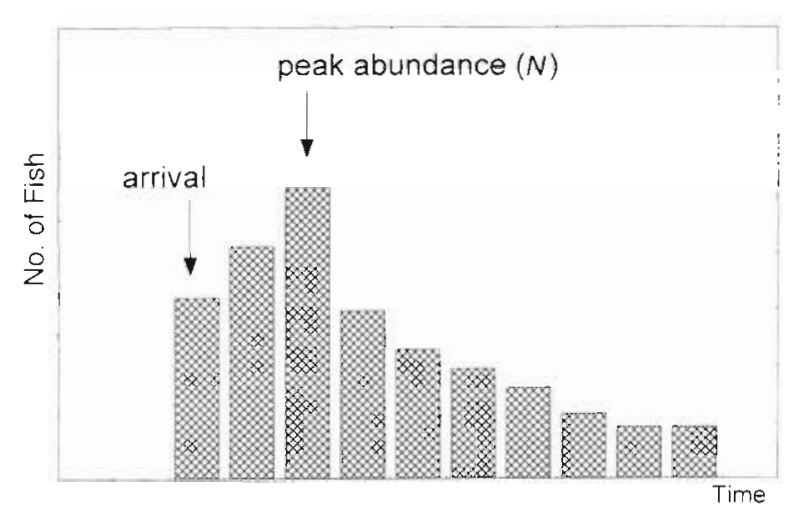

Fig. 2. Diplodus spp. Schematic representation of the settlement pattern of 3 Diplodus species. $N$ is the number of individuals recorded at peak abundance

(Fig. 2). The peak number of settlers gave the best estimate of settlement for that year, as the number of fishes recorded at each station greatly varied in time. It increased rapidly during the settlement period, reached a peak and then decreased progressively when mortality predominated over arrival. As stations differed in size within and between sites, we standardized data $(D)$ by dividing the maximum number of individuals $(N)$ recorded at each station by the coastal length of the station expressed in metres $(L): D=N / L$. Thus, $D$ was the maximum number of settlers recorded per linear coastal metre at the station level. At the site scale a mean standardized settlement intensity $\left(D_{\mathrm{m}}\right)$ was calculated each year by combining data from all stations. If $D$ accounted best for settlement intensity at the station level, it did not necessarily reflect the final abundance of juveniles recruited into the population, as the initial number of settlers might be highly and diversely modified by differential mortality rates, as discussed by Macpherson et al. (1997). The minimum size at settlement was around $10 \mathrm{~mm}$ total length (range 8 to $15 \mathrm{~mm} \mathrm{TL}$ ) in the 3 species.

A 2-factor analysis of variance (ANOVA) was used to examined variability in settlement intensity on both small and large spatial scales. Within each site (small scale), differences in settlement intensity were tested among stations and among years. Data were included only from years where all stations at a site were sampled. Data were $\log$-transformed $\left[\log _{e}(D+1)\right]$ prior to analysis to homogenize variance (Bartlett's test, $\mathrm{p}>$ $0.05)$. Mean settlement $\left(D_{\mathrm{m}}\right)$ was tested among sites and years. Comparisons between specific sites were made using a Student-Newman-Keuls test. A 3-way ANOVA with stations nested within sites and with years as another factor was not possible owing to missing data. The effect of protection level on settlement intensity was tested by combining data from Girona, Banyuls and Marseille, where stations were located 
both in protected and unprotected areas. Differences were tested by Mann-Whitney $U$-test of comparison of means.

\section{RESULTS}

\section{Seasonality of settlement}

Seasonality of settlement of juvenile fish on Mediterranean rocky shores was high for each of the 3 species. Diplodus sargus settled mainly from May to June, D. puntazzo from October to late November, and D. vulgaris from November to February, generally in 2 pulses (Fig. 3). The maximum number of settlers was recorded from 2 to $4 \mathrm{wk}$ after the arrival of the first settlers. The time elapsed between the first count and the peak in abundance gave an indication of the minimum duration of the settlement period. A shift between years in the timing of settlement was observed in all sites. Settlement of $D$. sargus occurred earlier in 1995 (May) than in 1993 and 1994 (June) and for a longer period, as the peak was observed more than $6 \mathrm{wk}$ after the arrival of the first settlers instead of 2 to $3 \mathrm{wk}$ the preceding years (Fig. 3A).

The arrival and the abundance peak of Diplodus puntazzo occurred 1 mo later in 1993 (November) than in 1994 and 1995, and the duration of the settlement period was twice as long in 1993 as in the 2 following years (Fig. 3B). D. vulgaris settled in 2 well-separated pulses, the first centred around the end of November (from late October to late December) and the second from January to February, in 1993 and 1994 (Fig. 3C). However, in 1995, the first pulse only was observed in all sites, and the second pulse did not occur. The settlement period generally lasted for 2 to $3 \mathrm{wk}$ for this species, whatever the pulse. As the first and second pulses of settlement of $D$. vulgaris occurred in different calendar years, we used the year of the first arrival to put data into years (e.g. data on settlement from October 1993 to February 1994 appear as '1993').

\section{Small-scale spatio-temporal variability}

The spatial variability of settlement at a small scale was high for each species (Tables 1 to 3 ). Differences greater than 1 order of magnitude were observed between adjacent stations separated by only tens to hundreds of metres. The rank of stations generally varied from year to year, as emphasized by the significant interaction between station and year. The factor 'Station' was highly significant at all sites for each species, indicating that mean number of settlers differed highly between stations within sites. However, this factor
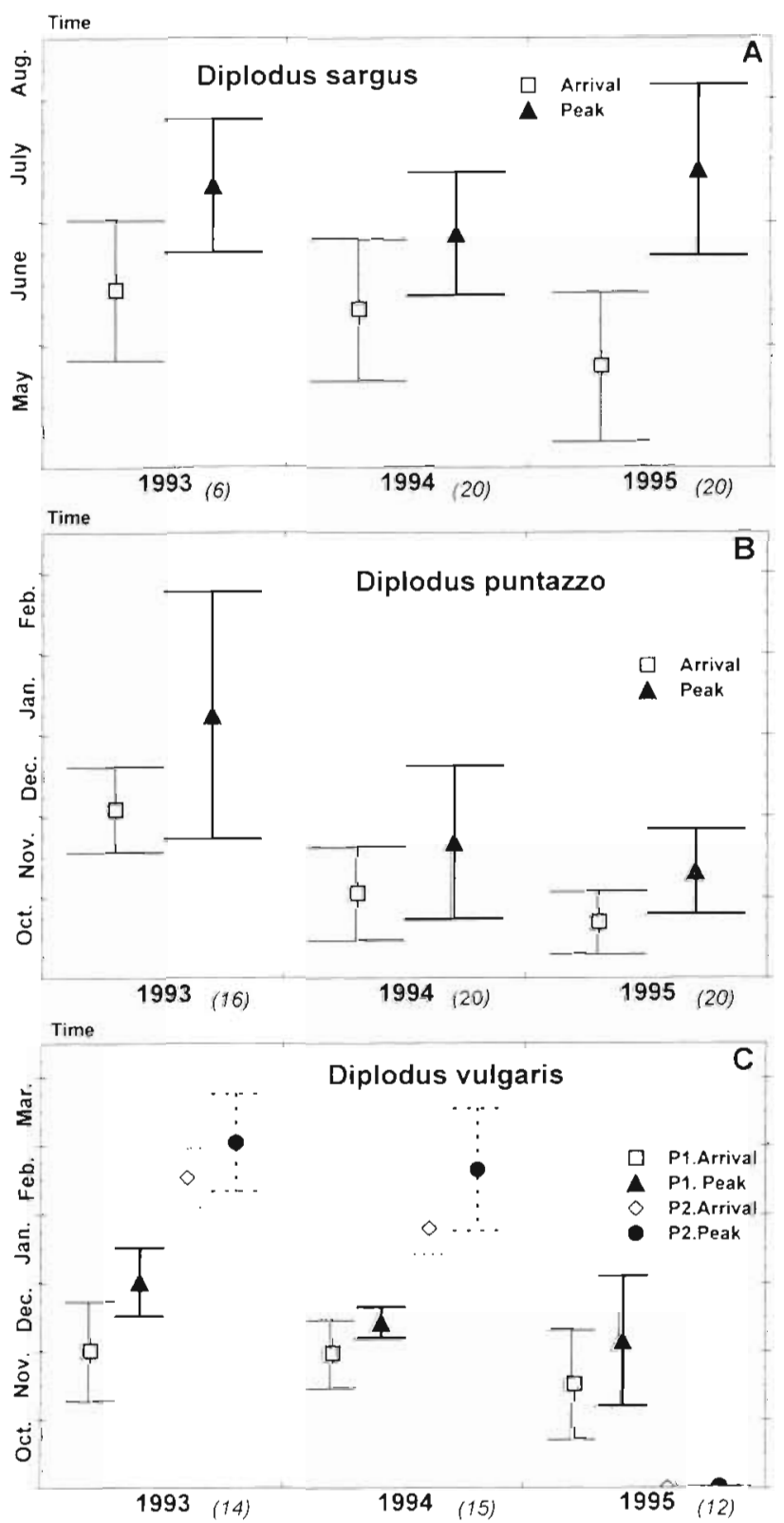

Fig. 3. Diplodus spp. Mean dates ( \pm SD) of arrival and peak abundance at settlement of (A) D. sargus, (B) D. puntazzo, and (C) D. vulgaris (P1: pulse 1, P2: pulse 2) in the northwestern Mediterranean from 1993 to 1995. Number of data per year is indicated in italics

generally explained a lower percentage of variance than did the factor 'Year', which predominated at all sites, except at Elba for Diplodus puntazzo and $D$. vulgaris. The small-scale spatial variability in settlement of D. sargus was high (Table 1). The rank of stations varied from year to year in all sites, except at Marseille, where settlement was always higher at station MA3UP. Similar trends in year-to-year variation in set- 
Table 1 Diplodus sargus. Within-site variability of D. sargus settlement intensity in space and time. Results of the 2-way analyses of variance performed on transformed data using $\log _{e}(D+1)$, where $D$ is the maximum number of settlers per linear coastal metre. \% variance: percentage of the total variance explained by each factor. $\cdots p<0.001$

\begin{tabular}{|llrlll|}
\hline Site & Factor & df & \multicolumn{1}{c}{$F$} & p & $\%$ variance \\
\hline Girona & Station & 2 & 1015.7 & $\ldots$ & 22.7 \\
(Spain) & Year & 1 & 4999.5 & $\ldots$ & 55.9 \\
& Station $\times$ Year & 2 & 950.8 & $\cdots$ & 21.3 \\
Banyuls & Station & 2 & 112.3 & $\ldots$ & 10.9 \\
(France) & Year & 1 & 1179.8 & $\ldots$ & 57.2 \\
& Station $\times$ Year & 2 & 316.6 & $\ldots$ & 30.8 \\
Marseille & Station & 3 & 131.9 & $\ldots$ & 22.7 \\
(France) & Year & 1 & 582.1 & $\ldots$ & 66.9 \\
& Station $\times$ Year & 3 & 24.1 & $\cdots$ & 8.7 \\
Portofino & Station & 3 & 664.8 & $\ldots$ & 28.1 \\
(Italy) & Year & 1 & 4184.4 & $\ldots$ & 58.9 \\
& Station $\times$ Year & 3 & 301.0 & $\cdots$ & 12.7 \\
Elba & Station & 2 & 436.1 & $\ldots$ & 33.1 \\
(Italy) & Year & 1 & 1298.2 & $\ldots$ & 49.2 \\
& Station $\times$ Year & 2 & 225.2 & $\cdots$ & 17.0 \\
\hline
\end{tabular}

tlement intensity for this species occurred at all sites. From Spain to Italy, 1994 was a year of higher settlement for D. sargus than were 1995 and 1993 (Fig. 4). The decrease in settlement intensity from 1994 to 1995 was $44 \%$ in Marseille, whereas it reached $80 \%$ in Girona, $75 \%$ in Banyuls, $78 \%$ in Portofino, and $74 \%$ at Elba Island. In 1993, settlement was lower than in 1995 in both Girona and Marseille.

The spatial variability in Diplodus puntazzo settlement at a small scale was also high (Table 2). The rank order of stations changed with year in all sites, except at Elba, where station EL3UP was always ranked first. Settlement of $D$. puntazzo varied differently from year to year at each site (Fig. 5). In Girona, no difference occurred from 1993 to 1994 , but a drastic decrease (92\%) was observed in 1995. In Banyuls, Portofino and Elba an increase was observed from 1993 to 1994, followed by a clear decrease in 1995 , but the lowest settlement was recorded in 1995 for Banyuls and Portofino and in 1993 for Elba. In Marseille, settlement of $D$. puntazzo was high both in 1993 and 1995 and significantly lower in 1994 (mean decrease $85 \%$ ).

Settlement of Diplodus vulgaris was consistently higher at station BA3UP and at station EL3UP during the 3 years. In the other sites, the rank order of stations varied from year to year (Table 3). Interannual variation in settlement of $D$. vulgaris differed among sites. In the western sites, Girona and Banyuls, the highest abundance of settlers was observed in 1993, whereas the highest settlement intensity in the eastern sites,
Table 2. Diplodus puntazzo. Within-site variability of $D$. puntazzo settlement intensity in space and time. Results of the 2way analyses of variance performed on transformed data using $\log _{e}(D+1)$, where $D$ is the maximum number of settlers per linear coastal metre. \% variance: percentage of the total variance explained by each factor. $\cdots p<0.001$

\begin{tabular}{|c|c|c|c|c|c|}
\hline Site & Factor & $d f$ & $F$ & $\mathrm{p}$ & $\%$ variance \\
\hline $\begin{array}{l}\text { Girona } \\
\text { (Spain) }\end{array}$ & $\begin{array}{l}\text { Station } \\
\text { Year } \\
\text { Station } \times \text { Year }\end{array}$ & $\begin{array}{l}2 \\
2 \\
4\end{array}$ & $\begin{array}{r}1266.8 \\
2518.1 \\
800.9\end{array}$ & $\begin{array}{l}\cdots \\
\cdots \\
\cdots\end{array}$ & $\begin{array}{l}23.4 \\
46.6 \\
29.7\end{array}$ \\
\hline $\begin{array}{l}\text { Banyuls } \\
\text { (France) }\end{array}$ & $\begin{array}{l}\text { Station } \\
\text { Year } \\
\text { Station } \times \text { Year }\end{array}$ & $\begin{array}{l}2 \\
2 \\
4\end{array}$ & $\begin{array}{r}95.7 \\
1440.3 \\
126.2\end{array}$ & $\begin{array}{l}\cdots \\
\cdots \\
\cdots\end{array}$ & $\begin{array}{r}5.1 \\
78.9 \\
15.3\end{array}$ \\
\hline $\begin{array}{l}\text { Marseille } \\
\text { (France) }\end{array}$ & $\begin{array}{l}\text { Station } \\
\text { Year } \\
\text { Station } \times \text { Year }\end{array}$ & $\begin{array}{l}3 \\
2 \\
6\end{array}$ & $\begin{array}{r}441.2 \\
1574.6 \\
319.0\end{array}$ & $\cdots$ & $\begin{array}{l}20.6 \\
49.0 \\
29.8\end{array}$ \\
\hline $\begin{array}{l}\text { Portofino } \\
\text { (Italy) }\end{array}$ & $\begin{array}{l}\text { Station } \\
\text { Year } \\
\text { Station } \times \text { Year }\end{array}$ & $\begin{array}{l}3 \\
1 \\
3\end{array}$ & $\begin{array}{r}960.0 \\
7254.1 \\
1424.8\end{array}$ & $\begin{array}{l}\cdots \\
\cdots \\
\cdots\end{array}$ & $\begin{array}{l}20.6 \\
49.9 \\
29.3\end{array}$ \\
\hline $\begin{array}{l}\text { Elba } \\
\text { (Italy) }\end{array}$ & $\begin{array}{l}\text { Station } \\
\text { Year } \\
\text { Station } \times \text { Year }\end{array}$ & $\begin{array}{l}2 \\
2 \\
4\end{array}$ & $\begin{array}{r}1560.4 \\
778.7 \\
479.3\end{array}$ & $\begin{array}{l}\cdots \\
\cdots \\
\cdots\end{array}$ & $\begin{array}{l}47.1 \\
23.6 \\
28.9\end{array}$ \\
\hline
\end{tabular}

Table 3. Diplodus vulgaris. Within-site variability of $D$. vulgaris settlement intensity in space and time. Results of the 2 -way andyses of variance performed on transformed data using $\log _{d}(D+1) . D$ is the maximum number of settlers per linear coastal metre. \% variance: percentage of the total variance explained by each factor, $\cdots p<0.001$, ns: $p>0.05$. Girona data were not analyzed, as only one station at Girona was studied for $D$. vulgaris

\begin{tabular}{|c|c|c|c|c|c|}
\hline Site & Factor & $\mathrm{df}$ & $F$ & $\mathrm{p}$ & $\%$ variance \\
\hline \multirow{3}{*}{$\begin{array}{l}\text { Banyuls } \\
\text { (France) }\end{array}$} & Station & 2 & 33.2 & $\cdots$ & 9.7 \\
\hline & Year & 1 & 596.0 & $\cdots$ & 86.7 \\
\hline & Station $\times$ Year & 2 & 3.4 & ns & 1.0 \\
\hline \multirow{3}{*}{$\begin{array}{l}\text { Marseille } \\
\text { (France) }\end{array}$} & Station & 3 & 333.3 & $\cdots$ & 30.0 \\
\hline & Year & 1 & 2051.7 & $\cdots$ & 61.5 \\
\hline & Station $\times$ Year & 3 & 862 & $\cdots$ & 7.7 \\
\hline \multirow{3}{*}{$\begin{array}{l}\text { Portofino } \\
\text { (Italy) }\end{array}$} & Station & 3 & 249.5 & $\cdots$ & 20.6 \\
\hline & Year & 1 & 487.7 & $\cdots$ & 49.9 \\
\hline & Station $\times$ Year & 3 & 74.5 & $\cdots$ & 15.1 \\
\hline \multirow{3}{*}{$\begin{array}{l}\text { Elba } \\
\text { (Italy) }\end{array}$} & Station & 2 & 1560.4 & $\cdots$ & 60.4 \\
\hline & Year & 2 & 778.7 & $\cdots$ & 29.2 \\
\hline & Station $\times$ Year & 4 & 260.2 & $\cdots$ & 10.2 \\
\hline
\end{tabular}

Marseille, Portofino and Elba, was observed in 1994 (Fig. 6). Diplodus vulgaris generally settled in 2 pulses, the first in November-December and the second, which was generally the highest, in January-February. This pattern was obvious in Marseille, where the 2 pulses were separated (Table 4). In 1995, this species recruited in one pulse only (November) at all sites. 


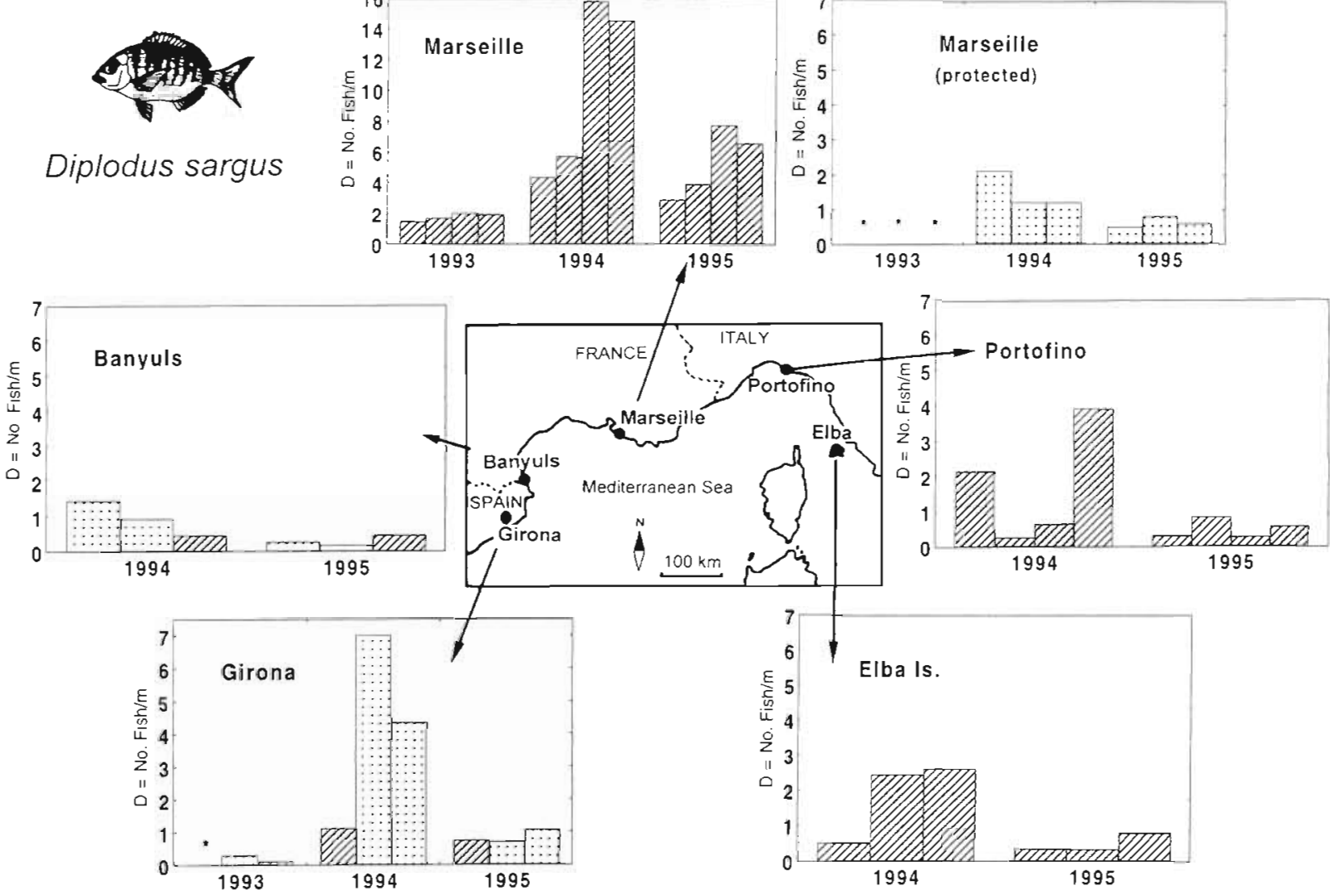

Fig. 4. Diplodus sargus. Settlement across the NW Mediterranean between 1993 and 1995 (ranking of stations is similar in each site each year with Stn 1 to the left). Hatched bars: stations located in unprotected zones, dotted bars: stations located in protected zones. 'Stations not surveyed. Note difference in scale for the unprotected Marseille stations

Table 4. Diplodus vulgaris. Difference in settlement intensity between pulse 1 and pulse 2 for $D$. vulgaris in Marseille in 1993 and 1994 (means $\pm S D, n=4$ ). p; significance of SNK test of comparison of means between pulses $[p(p)]$ and years $[p(y)]$, ns: not significant

\begin{tabular}{|cccc|}
\hline & 1993 & 1994 & $\mathrm{p}(\mathrm{y})$ \\
\hline Pulse 1 & $3.696 \pm 2.227$ & $1.249 \pm 2.023$ & $\mathrm{~ns}$ \\
Pulse 2 & $5.529 \pm 0.466$ & $77.421 \pm 42.780$ & $\mathrm{p}=0.02$ \\
$\mathrm{p}(\mathrm{p})$ & ns & $\mathrm{p}<0.02$ & \\
\hline
\end{tabular}

\section{Large-scale spatio-temporal variability}

A large difference in the intensity of settlement of Diplodus sargus, D. puntazzo and D. vulgaris was observed among sites during the $3 y$ r study (Table 5). A significant difference in settlement between sites was found for each species, but significant interaction between site and year existed for 2 species (Table 6). At a large spatial scale, the factor 'Site' explained a higher percentage of variance than the factor 'Year', which was not significant for 2 species. For D. sargus, the rank of sites did not change with time, as indicated by the non-significant interaction between Site and Year, with highest settlement in Marseille, then Girona, Portofino, Elba and finally Banyuls. Significant interannual variation in settlement of $D$. sargus was observed at the large spatial scale, with 1994 values being higher than those of 1995 . The intensity of settlement of $D$. puntazzo was significantly higher in Marseille, Elba and Girona than in Portofino and Banyuls, but the rank order of sites varied from year to year. Settlement of $D$. puntazzo was highest in Marseille in 1993 and 1995 and at Elba in 1994. Settlement of $D$. vulgaris was consistently highest in Marseille during the 3 yr study, but the rank of the other sites varied from year to year. Lowest settlement was observed in Portofino in 1993 and 1995 and in Banyuls in 1994.

\section{Effect of protection level}

Mean numbers of settlers were higher in unprotected areas, but these differences were not significant (Table 7). At a small spatial scale, contrasting results 


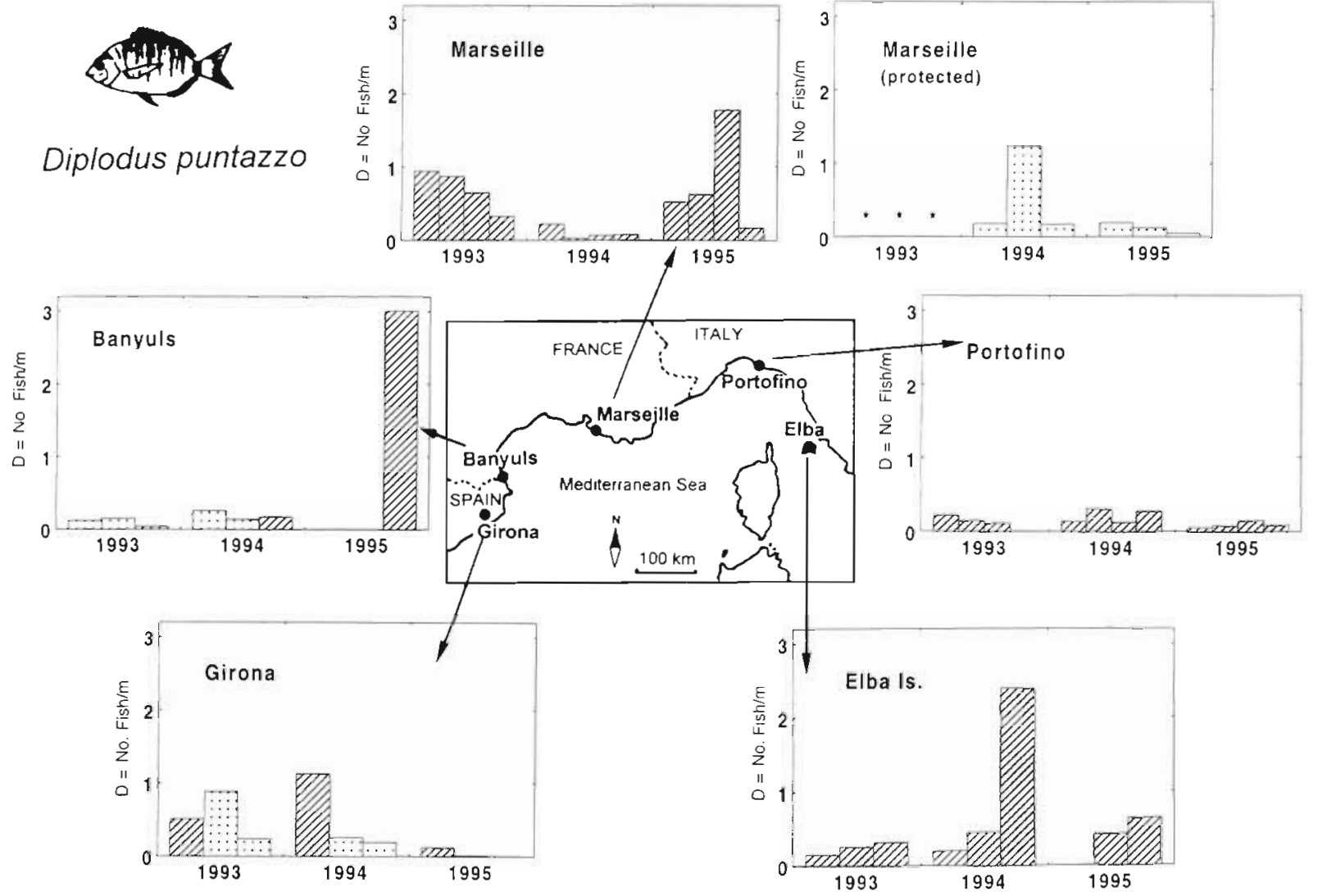

Fig. 5. Diplodus puntazzo. Settlement across the NW Mediterranean between 1993 and 1995 (ranking of stations is similar in each site each year with Stn 1 to the left). Hatched bars: stations located in unprotected zones, dotted bars: stations located in protected zones. 'Stations not surveyed

Table 5. Diplodus spp. Mean density $\left(D_{\mathrm{rn}}\right)$ of settling $D$. sargus, $D$. puntazzo and $D$. vulgaris at abundance peak (mean number of settlers per coastal metre \pm SD) in the NW Mediterranean according to sites and years. nd: no data collected

\begin{tabular}{|lcccccc|}
\hline Species & Year & Girona & Banyuls & Marseille & Portofino & Elba \\
\hline D. sargus & 1993 & $0.134 \pm 0.150$ & nd & $1.778 \pm 0.231$ & nd & nd \\
& 1994 & $4.159 \pm 2.948$ & $0.946 \pm 0.500$ & $6.374 \pm 6.214$ & $1.740 \pm 1.654$ & $1.861 \pm 1.163$ \\
& 1995 & $0.840 \pm 0.201$ & $0.300 \pm 0.143$ & $3.261 \pm 2.942$ & $0.499 \pm 0.272$ & $0.495 \pm 0.258$ \\
D. puntazzo & 1993 & $0.543 \pm 0.323$ & $0.103 \pm 0.062$ & $0.624 \pm 0.412$ & $0.163 \pm 0.064$ & $0.246 \pm 0.084$ \\
& 1994 & $0.530 \pm 0.524$ & $0.187 \pm 0.062$ & $0.111 \pm 0.071$ & $0.216 \pm 0.094$ & $1.012 \pm 1.199$ \\
& 1995 & $0.044 \pm 0.065$ & $0.004 \pm 0.008$ & $0.777 \pm 0.696$ & $0.091 \pm 0.042$ & $0.356 \pm 0.326$ \\
D. vulgaris & 1993 & 5.917 & $2.750 \pm 1.005$ & $5.791 \pm 0.178$ & $0.683 \pm 0.561$ & $2.965 \pm 1.771$ \\
& 1994 & 3.251 & $0.307 \pm 0.221$ & $77.416 \pm 42.779$ & $1.886 \pm 1.117$ & $3.755 \pm 4.162$ \\
& 1995 & 3.535 & nd & $9.263 \pm 9.205$ & $0.739 \pm 0.361$ & $0.883 \pm 0.773$ \\
\hline
\end{tabular}

were obtained depending on site and species. In Girona, the settlement of Diplodus sargus was significantly higher at protected stations, and in unprotected stations for D. puntazzo and D. vulgaris (Figs. 4 to 6). In Banyuls, the settlement of $D$. sargus was higher in protected stations in 1994 and lower in 1995, and always higher in protected stations for D. puntazzo. In Marseille, D. sargus settled in higher number in unprotected stations, but no difference was observed for $D$. puntazzo. Thus, no obvious or consistent pattern in settlement intensity emerged with respect to the protection level of stations for the 3 species. 


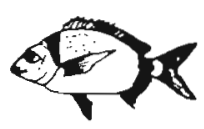

Diplodus vulgaris
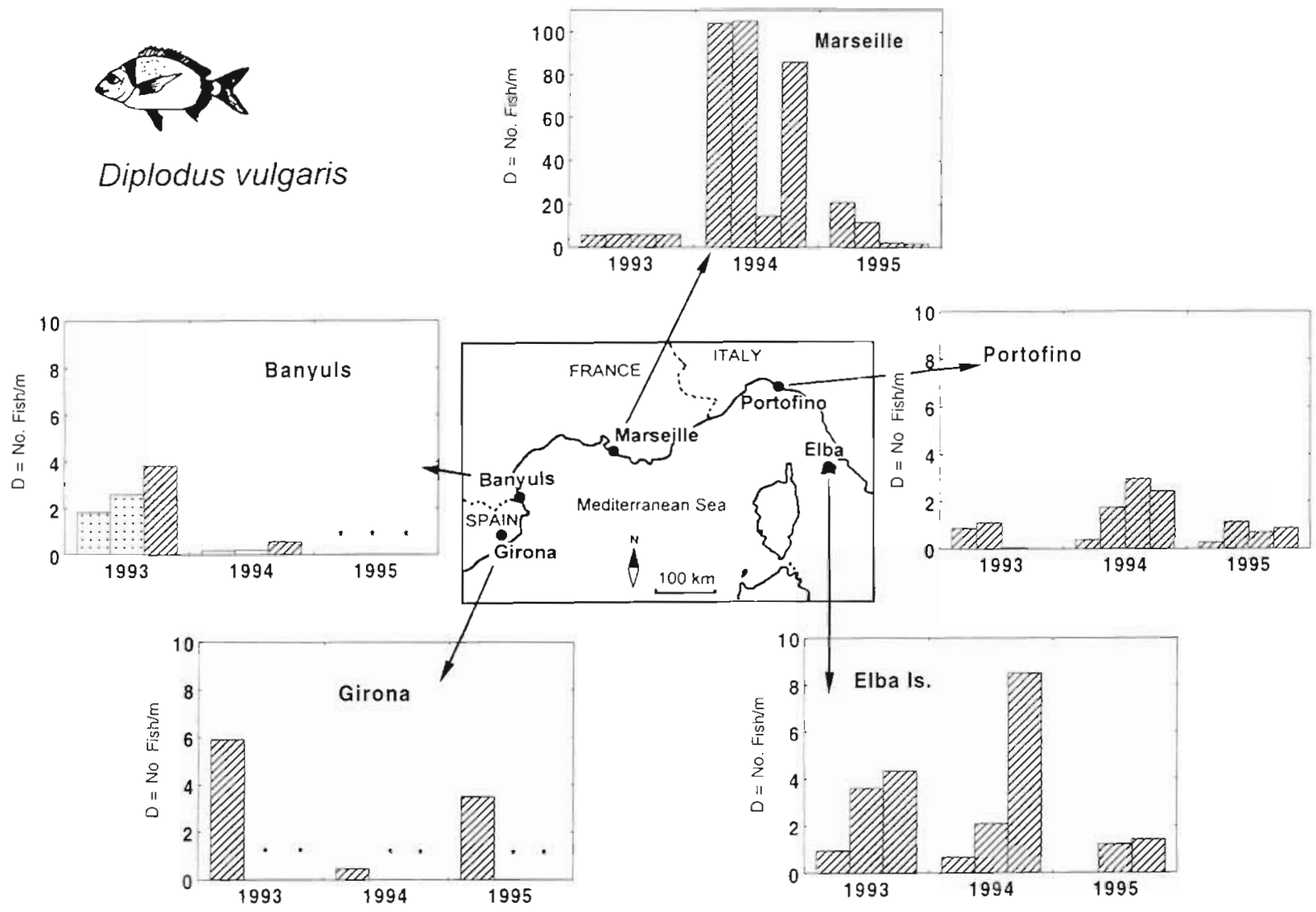

Fig. 6. Diplodus vulgaris. Settlement across the NW Mediterranean between 1993 and 1995 (ranking of stations is similar in each site each year with Stn 1 to the left). Hatched bars: stations located in unprotected zones, dotted bars: stations located in protected zones. "Stations not surveyed. Note difference in scale for the unprotected Marseille stations

\section{Relative importance of species}

Settlement intensity varied among species as well as among stations, sites and years. In total, Diplodus puntazzo represented $4.2 \%$ of the total number of sparid settlers recorded, $D$. sargus $24.8 \%$ and $D$. vulgaris $71.0 \%$. At all sites, D. puntazzo settled with the lowest intensity, representing from 2.8 to $5.4 \%$ of the total number of sparid recruits in 1994, and from 0.2 to $29.0 \%$ in 1995. Diplodus sargus and $D$. vulgaris were more abundant and dominated at different sites with time. Opposite trends were observed in the respective proportions of these 2 species in the western and in the eastern part of the NW Mediterranean. The proportion of $D$. vulgaris was higher in 1994 than in 1995 in Girona and Banyuls ( $64 \%$ vs $33 \%$ ). Conversely, it was lower in 1994 than in 1995 in Marseille, Portofino and Elba $(40 \%$ vs $78 \%$ ). The reverse was observed for $D$. sargus, which represented $32 \%$ of all Diplodus settlers in 1994 and $38 \%$ in 1995 at the western sites and 55\% in 1994 versus $13 \%$ in 1995 at the eastern sites.

\section{DISCUSSION}

Many authors working on coral reef fishes have emphasized the variability in settlement and recruitment both in space and time, implying that recruitment of juveniles was largely a stochastic process (Doherty 1987, 1991, Doherty \& Williams 1988, Sale 1991). However, some coherent patterns now suggest the involvement of deterministic processes (Victor 1983, 1986 , Cowen 1985, Fowler et al. 1992). Our study showed that the settlement of sparids in the NW Mediterranean was highly variable in space and time, but presented some consistent patterns, probably related to hydroclimatic factors acting on several spatial and temporal scales.

Sparid settlement has typically been studied with beach seines or other devices which catch juveniles larger than 20 to $25 \mathrm{~mm}$ TL (Ranzi 1930, Quignard et al. 1984, Jug-Dujakovic 1988). Using visual censuses, we have demonstrated that settlement for the 3 Diplodus species studied here occurred at about $10 \mathrm{~mm}$ TL. 
Table 6. Diplodus spp. Two-way ANOVA performed on transformed data using $\log \left(D_{\mathrm{m}}+1\right)$ comparing differences in mean settlement intensity of $D$. sargus, $D$. puntazzo and $D$. vulgaris between sites and years. $p<0.05, \cdots p<0.01, \cdots p<0.001$, $n s: p>0.05$ ) $\%$ variance: percentage of the total variance explained by each factor

\begin{tabular}{|llcccc|}
\hline Species & Factor & df & $F$ & p & $\%$ variance \\
\hline D. sargus & Site & 4 & 4.455 &. & 31.5 \\
& Year & 1 & 7.964 &. & 14.1 \\
& Site $\times$ Year & 4 & 0.183 & ns & 1.3 \\
D. puntazzo & Site & 4 & 3.455 & $\cdot$ & 20.0 \\
& Year & 2 & 0.977 & ns & 2.9 \\
& Site $\times$ Year & 8 & 2.533 & $\cdot$ & 29.4 \\
D. vulgaris & Site & 3 & 30.358 & $\ldots$ & 61.2 \\
& Year & 1 & 4.169 & ns & 2.8 \\
& Site $\times$ Year & 3 & 1.181 & $\cdots$ & 22.5 \\
\hline
\end{tabular}

This technique allowed us to determine the actual timing of settlement: May-June for D. sargus, OctoberNovember for D. puntazzo, and November to February for $D$. vulgaris. The 3 Diplodus species exhibited similar habitat requirements at settlement, but were segregated on a clear seasonal basis, with each species occupying the same nursery ground successively, except for a short overlap between D. puntazzo and the first pulse of D. vulgaris (Garcia-Rubies \& Macpherson 1995. Harmelin-Vivien et al. 1995). The succession in settlement time could potentially circumvent competition between related species for food and shelter resources.

Small-scale spatio-temporal variability in settlement abundance of the 3 Diplodus species was high at all sites. Dates of arrival and peak abundance, and the maximum number of settling individuals varied greatly between stations within each site. The rank of stations changed from year to year and among species in most sites, except for a few stations which always harboured more individuals, such as Stn EL3UP. These data implied that microhabitat characteristics were not the only factor explaining small-scale variability in Diplodus settlement, whereas they could affect settlement patterns at that scale (Tolimieri 1995). Differ- ences in settlement between stations could be partly attributed to the patchy distribution of pre-settling fish, as suggested by the 'larval patch' hypothesis developed to explain the spatial variability of recruitment patterns over scales of metres to kilometres (Cowen 1985, Victor 1986, Doherty \& Williams 1988). At a small scale, time was more important than space for explaining the high variability in sparid settlement. In each site, year-to-year variations in settlement of the 3 Diplodus species were higher than variations between stations. Nevertheless, significant interactions between year and station indicated that, to accurately record temporal variation in settlement, different stations per site should be sampled.

At a large scale, Diplodus settlement was also highly variable, but differences between sites predominated over differences between years. The consistently higher settlement observed in Marseille and Girona may either be related to the topographic characteristics of the stations or reflect a real difference in regional influx of larvae. Tolimieri (1995) demonstrated that habitat did not influence recruitment variation on a large scale. As stations have been selected to present suitable microhabitats for sparid settlement, differences between sites were probably not related to habitat differences in this study. In some cases, the presence of suitable habitats does represent the main factor involved in differences between sites. The lack of sparid juveniles around certain islands in the Marseille area is explained by the absence of suitable habitats on abrupt coasts (Harmelin-Vivien et al. 1995). Cowen (1985) found that recruitment occurred consistently from year to year in areas with larval sources upstream, whereas in areas out of the typical larval flux, recruitment was highly variable and dependent upon anomalous flow events. Little is known of where Diplodus spp. spawn in the NW Mediterranean, except that spawning sites are probably located deeper on the continental shelf (Divanach 1985). The few sparid larvae sampled by Sabates (1990) and Sabates \& Olivar (1996) were collected far from the coast, suggesting that dispersal by hydrographic processes during the pelagic life is important. Thus, information on spawn-

Table 7. Diplodus sargus and Diplodus puntazzo. Effect of protection level on settlement intensity of $D$. sargus and $D$. puntazzo in the NW Mediterranean. Data from Girona, Banyuls and Marseille were combined (mean number of fish per coastal metre $\pm \mathrm{SD}$ ). $n$ : number of stations; $n$ : $\mathrm{p}>0.05$

\begin{tabular}{|lcccccc|}
\hline Species & Year & $\mathrm{n}$ & Protected & $\mathrm{n}$ & Unprotected & Result \\
\hline D. sargus & 1994 & 7 & $2.599 \pm 2.268$ & 6 & $6.947 \pm 6.649$ & $\mathrm{~ns}$ \\
& 1995 & 5 & $0.542 \pm 0.362$ & 6 & $3.598 \pm 2.894$ & $\mathrm{~ns}$ \\
D. puntazzo & 1993 & 7 & $0.426 \pm 0.444$ & 6 & $0.558 \pm 0.340$ & $\mathrm{~ns}$ \\
& 1994 & 7 & $0.174 \pm 0.076$ & 6 & $0.285 \pm 0.420$ & $\mathrm{~ns}$ \\
& 1995 & 4 & $0.006 \pm 0.007$ & 6 & $0.538 \pm 0.655$ & $\mathrm{~ns}$ \\
\hline
\end{tabular}


ing grounds and local coastal circulation would be necessary to understand the spatial. variability of sparid settlement in the Mediterranean. Finally, our analysis failed to find any effect of protection level on the intensity of settlement of the 3 species. Fishing pressure does not obviously influence the intensity of juvenile fish settlement into benthic habitats, contrary to what has been demonstrated for adult populations. It is now well-known that protection measures have increased fish diversity and abundance and individual size of adult fish populations in Mediterranean marine reserves (Bell 1983, Garcia-Rubies \& Zabala 1990, Francour 1994, Dufour et al. 1995. Harmelin et al. 1995).

Some coherent temporal patterns were also observed at a large scale. Interannual differences in the date of maximum abundance were similar at all sites The settlement of Diplodus sargus and D. vulgaris peaked earlier in 1994 than in 1993, and the peak abundance of $D$. puntazzo occurred earlier in 1995 than in the 2 preceding years. Differences in the timing of peaks of settlement may relate to variation in the date of adult reproduction or the duration of the pelagic life. Similar trends in year-to-year variability of settlement intensity were observed at a large spatial scale in 2 of the 3 species. The level of settlement of $D$. sargus was higher in 1994 than in 1995 at all 5 of the sites, which are spread along approximately $1000 \mathrm{~km}$ of coast line. This could not be related to habitat variability, as habitat characteristics of stations did not change from year to year. The consistency of interannual variation in settlement intensity of $D$. sargus, which settled in May-June, suggested the influence of strong large-scale deterministic processes operating over distances of hundreds of kilometres during that period. Individuals recorded at the different sites likely belonged to different local subpopulations, which certainly reproduced in different areas, as evidenced by a genetic study on D. sargus (Lenfant \& Planes 1996). Nevertheless, the consistent feature of year-to-year variation observed in this species suggested that hydroclimatic conditions were stable and similar in the whole NW Mediterranean during larval life and the settlement period (end of spring to beginning of summer) and have influenced the various subpopulations in a similar way. In a study on temperate flatfishes, Henderson \& Seaby (1994) demonstrated that temperature during the spawning and larval period may directly influence the abundance of juveniles. In $D$. puntazzo and $D$. vulgaris different trends in interannual variations in settlement intensity were observed among sites. The absence of a general pattern of yearto-year variation might be related to unstable conditions in coastal waters in late autumn and winter, the period of benthic settlement of these 2 species.
Settlement of the Diplodus species varied as much as 1 order of magnitude from year to year. In temperate commercial fishes, recruitment variability is largely attributed to survivorship during the egg and larval stages (Gulland 1982, Cushing 1988), when starvation and predation are major mortality factors (Leggett \& Deblois 1994). The general pattern observed over the whole NW Mediterranean in interannual variations of $D$. sargus tends to confirm that settlement is controlled by factors operating at a large spatial scale occurring at the pelagic life-history stage. Favourable general hydroclimatological factors in 1994 may have enhanced the success of one or several of various processes, such as reproduction, egg fertilization, larval survivorship, food supply, and advection of larvae to settlement sites. To understand the differences in temporal variability of settlement among species would require correlation of the interannual fluctuations in settlement with differences in hydrological and climatological conditions over time.

The implications of this study are important not only for understanding the dynamics of sparid populations, but also in terms of management of these resources in the Mediterranean, which requires discrimination between the natural variability of settlement and changes due to anthropogenic disturbances of coastal waters. Our data showed consistent patterns both in space and time that implicate deterministic processes of sparid settlement in the Mediterranean at a large scale, which may differ from species to species in spite of high variability at a small-scale. Such natural variability may be still emphasized by a degradation of coastal habitats which constitute the nursery grounds of many littoral fishes, resulting in greater instability in the size of local fish populations.

Acknowledgements. Thanks are expressed to V. Dufour and S. Planes (EPHE/URA 1453 Montpellier), to P. Francour (COM/UMR 6540 Marseille), to L. Mariani, M. Mori and H. Vacchi (ICRAM Roma) and S. Gambaccini and M. Zazzetta (Universita da Pisa \& ClBM Livorno) for their assistance in collecting data and for discussions, and to Sally Leys for improving the English in the manuscript. Helpful comments and suggestions from 4 anonymous reviewers improved the manuscript. This research was funded by the European Commission (DG XIV, MED/92/007).

\section{LITERATURE CITED}

Bas C, Macpherson E, Sarda F (1984) Fishes and fishermen The exploitable trophic levels. In: Margalef $R$ (ed) Key environments. Western Mediterranean. Pergamon Press, Oxford, p 296-316

Bell JD (1983) Effects of depth and marine reserve fishing restriction on the structure of a rocky reef fish assemblage in the north-western Mediterranean Sea. J Appl Ecol 20: $357-369$ 
Berghahn R (1986) Determining the abundance, distribution and mortality of 0 -group plaice (Pleuronectes platessa L.) in the Wadden sea. J Appl Ichthyol 2:11-22

Beverton RJ (1984) Dynamics of single species. In: May RM (ed) Exploitation of marine communities. Springer-Verlag, Berlin, p 13-58

Beverton RJ, Holt SJ (1957) On the dynamics of exploited fish populations. Fish Invest Ser II Mar Fish GB Minist Agric Fish 19:1-533

Biagi $F$, Gambaccini S, Zazzetta M (1997) Insediamento e microhabitat di specie ittiche nella fascia costeria toscana. Biol Mar Medit 4:195-203

Bolle LJ, Dapper R, Witte Jl, Van der Veer H (1994) Nursery grounds of dab (Limanda limanda L.) in the southern North Sea. Neth J Sea Res 32:299-307

Cambrony M (1984) Identification et périodicité du recrutement des juvéniles de Mugilidae dans les étangs littoraux du Languedoc-Roussillon. Vie Milieu 34:221-227

Carlson HR, Straty RR (1981) Habitat and nursery grounds of Pacific rockfish, Sebastes spp., in rocky costal areas of southeastern Alaska. Mar Fish Rev 43:13-19

Carr MH (1991) Habitat selection and recruitment of an assemblage of temperate zone reef fishes. J Exp Mar Biol Ecol 146:113-137

Connell JH (1985) The consequences of variation in initial settlement vs. post-settlement mortality in rocky intertidal communities. J Exp Mar Biol Ecol 93:11-45

Cowen RK (1985) Large scale pattern of recruitment by the labrid, Semicossyphus pulcher. causes and implications. J Mar Res 43:719-742

Cushing DH (1988) The study of stock recruitment. In: Gulland JA (ed) Fish population dynamics. John Wiley and Sons Ltd, New York, p 1.05-128

Divanach P (1985) Contribution à la connarssance de la biologie et de l'élevage de 6 Sparidés méditerranéens: Sparus aurata, Diplodus sargus, Diplodus vulgaris, Diplodus annularis, Lithognathus mormyrus, Puntazzo puntazzo (Poissons Téléostéens). Thèse d'Etat, Univ Sci Tech Languedoc

Doherty PJ (1987) The replenishment of populations of coral reef fishes, recruitment surveys, and the problems of variability manifest on multiple scales. Bull Mar Sci 41: $411-422$

Doherty PJ (1991) Spatial and temporal patterns in recruitment. In: Sale PF (ed) The ecology of fishes on coral reefs. Academic Press, London, p 261-293

Doherty PJ, Fowler T (1994) An empirical test of recruitment limitation in a coral reef fish. Sclence 263:935-939

Doherty PJ, Williams D MCB (1988) The replenishment of coral reef fish populations. Oceanogr Mar Biol Annu Rev $26: 487-551$

Dufour V, Jouvenel JY, Galzin R (1995) Study of a Mediterranean reef fish assemblage. Comparison in population distribution between depths in protected and unprotected areas over one decade. Aquat Liv Res 8:17-25

Folkvord A, Blom G, Dragesund O, Johannessen A (1994) A conceptual framework for enhancing and studying recruitment of marine fish stocks. Aquacult Fish Manag (Suppl 1) 25:245-258

Fowler AJ, Doherty PJ, Williams D McB (1992) Multi-scale analysis of recruitment of a coral reef fish on the Great Barrier Reef. Mar Ecol Prog Ser 82:131-141

Francour P (1994) Pluriannual analysis of the reserve effect on ichthyofauna in the Scandola natural reserve (Corsica, Northwestern Mediterranean). Oceanol Acta 17:309-317

Garcia-Rubies A, Macpherson E (1995) Substrate use and temporal pattern of recruitment in juvenile fishes of the
Mediterranean luttoral. Mar Biol 124:35-42

Garcia-Rubies A, Zabala M (1990) Effect of total fishing prohibition on the rocky fish assemblages of Medes Island marine reserve. Sci Mar 54:317-328

Gibson RN (1994) lmpact of habitat quality and quantity on the recruitment of juvenile flatfishes. Neth $\mathrm{J}$ Sea Res 32: $191-206$

Gulland JA (1982) Why do fish numbers vary? J Theor Biol 97 $69-75$

Harmelin JG, Bachet F, Garcia F (1995) Mediterranean marine reserves: fish indices as tests of protection efficiency. PSZN I: Mar Ecol 16:233-250

Harmelin-Vivien ML, Harmelin JG, Leboulleux V (1995) Microhabitat requirements for settlement of juvenile sparid fishes on Mediterranean rocky shores. Hydrobiologia 300/301:309-320

Henderson PA, Seaby RMH (1994) On the factors influencing juvenile flatfish abundance in the Lower Severn estuary, England. Neth J Sea Res 32:321-330

Jennings S, Pawson MG (1992) The origin and recruitment of bass, Dicentrarchus labrax, larvae to nursery areas. J Mar Biol Assoc UK 72:199-212

Jug-Dujakovic J (1988) Growth and temporal distribution of juvenile sparids in the Sibenik area in the middle Adriatic. FAO Fish Rep 394:152-158

Leggett WC, Deblois E (1994) Recruitment in marine fishes: is it regulated by starvation and predation in the egg and larval stages? Neth J Sea Res 32:119-134

Lenfant P, Planes S (1996) Genetic differentiation of white sea bream within the Lion's Gulf and the Ligurian sea (Mediterranean Sea). J Fish Biol 49:613 621

Levin PS (1994) Fine-scale temporal variation in recruitment of a temperate demersal fish: the importance of settlement versus post-settlement loss. Oecologia 97:124-133

Levin PS (1996) Recruitment in a temperate demersal fish: Does larval supply matter? Limnol Oceanogr 41:672-679

Lough RG, Valentine PC, Potter DC, Auditore PJ, Bolz GR, Neilson JD, Perry RI (1989) Ecology and distribution of juvenile cod and haddock in relation to sediment type and bottom currents on eastern Georges bank. Mar Ecol Prog Ser 56:1-12

Macpherson E (1998) Ontogenetic shifts in habitat use and aggregation in juvenile sparid fishes.J Exp Mar Biol Ecol 220:127-150

Macpherson E, Bragi F, Francour P, Garcia-Rubies A, Harmelin JG, Harmelin-Vivien M, Jouvenel JY, Planes $S$, Vigliola L, Tunesi L. (1997) Mortality of juvenile fishes of the genus Diplodus in protected and unprotected areas in the western Mediterranean Sea. Mar Ecol Prog Ser 160: $135-147$

Miller JM (1994) An overview of the second flatfish symposium: recruitment in flatfish. Neth J Sea Res 32:103-106

Pauly D (1994) A framework for latitudinal comparisons of flatfish recruitment. Neth J Sea Res 32:107-118

Quignard JP, Man-Wai R, Vianet R (1984) Les poissons de l'étang de Mauguio (Hérault, France). Inventaire, structure du peuplement, croissance et polymorphisme des tailles. Vie Milieu 34:173-183

Ranzi S (1930) Stadi giovanili di Sparidi del Golfo di Napoli. Publ Stn Zool Napoli 18:282-312

Riley JD, Symons DJ, Woolner L (1981) On the factors influencing the distribution of 0 -group demersal fish in coastal waters. Rapp P-V Réun Cons Int Explor Mer 178:223-228

Sabates A (1990) Distribution pattern of larval fish populations in the northwestern Mediterranean. Mar Ecol Prog Ser 59:75-82

Sabates A, Olivar MP (1996) Variations of larval fish distribu- 
tions associated with variability in the location of a shelfslope front. Mar Ecol Prog Ser 135:11-20

Sale PF (1991) Reef fish communties: open nonequilibrial systems. In: Sale PF (ed) The ecology of fishes on coral reefs. Academic Press, London, p 564-598

Shulman MJ (1985) Variability in recruitment of coral reef fishes. J Exp Mar Biol Ecol 89.205-219

Tolimieri N (1995) Effects of microhabitat characteristics on the settlement and recruitment of a coral reef fish at two

Editorial responsibility: Otto Kinne (Editor),

Oldendorf/Luhe, Germany spatial scales. Oecologia 102:52-63

Tupper M, Boutilier RG (1995) Effects of conspecific density on settlement, growth and post-settlement survival of a temperate reef fish, J Exp Mar Biol Ecol 191:209-222

Victor BC (1983) Recruitment and population dynamics of a coral reef fish. Science 219:419-420

Victor BC (1986) Larval settlement and juvenile mortality in a recruitment-limited coral reef fish population. Ecol Monogr 56:145-160

Submitted: August 5, 1997; Accepted: March 30, 1998

Proofs received from author(s): June 15, 1998 